\title{
PRIMER PROCENE POTREBNOG KAPACITETA I TROŠKOVA OSNIVANJA JEDINICA ZA ODRŽAVANJE AUTOPUTEVA
}

Doc. dr Igor Jokanović, dipl.građ.inž. ${ }^{1}$ dr Dragan Mihajlović, dipl.građ.inž. ${ }^{2}$

UDK: 625.7:657.478

DOI: 10.14415/zbornikGFS27.10

Rezime: Uprkos brzom širenju mreže autoputeva u Azerbejdžanu, organizacija eksploatacije i održavanja autoputeva još uvek nije u potpunosti modernizovana. Trenutno je više od šezdeset regionalnih jedinica širom zemlje zaduženo za održavanje kompletne putne mreže. Ove jedinice izvršavaju svoje obaveze podjednako na magistralnim, regionalnim i lokalnim putevima. Moderan način eksploatacije autoputeva zahteva drugačiji pristup sa specifičnim procedurama i uređenjem odnosa za ovu vrstu mreže. Na osnovu postojeće organizacije i kapaciteta, kao i institucionalnih promena/jačanja unutar Agencije za državne puteve, utvrđeno je da se u određenom periodu mogu zadržati preduzeća iz javnog sektora kao davaoci usluga održavanja autoputeva. Ovakav predlog mora biti praćen organizacionim promenama u pogledu smanjenja postojećih jedinica kroz formiranje specijalizovanih regionalnih jedinica za održavanje autoputeva koje će biti odgovorne za duže sekcije/sektore od oko 200-300 km. U radu je prikazana analiza potrebnih kapaciteta za održavanje autoputne mreže u Azerbejdžanu, te procena ukupnih troškova uspostavljanja novih jedinica za održavanje autoputeva.

Ključne reči: eksploatacija, održavanje, kapacitet, troškovi, organizacija

\section{UVOD}

Modernizacija prakse upravljanja putevima u Azerbejdžanu je počela u toku 2011. godine donošenjem odluke Vlade o formalnom uspostavljanju Jedinice za autoputeve u okviru Agencije za državne puteve sa zadatkom da se osnaži upravljanje eksploatacijom i održavanjem autoputeva. Precizna definicija uloge Jedinice za autoputeve obuhvata sledeće aktivnosti:

- sveukupna odgovornost za aktivnosti eksploatacije i održavanja mreže autoputeva, uključujući upravljanje ugovorima, praćenje stanja, planiranje aktivnosti, ocenu realizacije i upravljanje podacima o putevima;

- dijalog sa Ministarstvom saobraćaja i Ministarstvom finansija, u ime Agencije za državne puteve, u vezi sa godišnjim budžetom, planiranjem aktivnosti u skladu sa

\footnotetext{
${ }^{1}$ Univerzitet u Novom Sadu, Građevinski fakultet Subotica, Kozaračka 2a, Subotica, Republika Srbija, e-mail: jokanovici@gf.uns.ac.rs

2 IG inženjering d.o.o. Trebinje, Ruska bb, Trebinje, Republika Srpska, Bosna i Hercegovina, e-mail: dram@ineco.net
} 
raspoloživim sredstvima, praćenjem i ocenom realizacije eksploatacije i održavanja mreže autoputeva.

Uprkos brzom širenju mreže autoputeva u Azerbejdžanu, aktivnosti upravljanja eksploatacijom i održavanjem još uvek nisu u potpunosti modernizovane. Trenutno je više od šezdeset regionalnih jedinica širom zemlje zaduženo za održavanje kompletne putne mreže. Ove jedinice izvršavaju svoje obaveze podjednako na magistralnim, regionalnim i lokalnim putevima, a posluju u sklopu Agencije za državne puteve. Moderan način eksploatacije autoputeva zahteva drugačiji pristup sa specifičnim procedurama $\mathrm{i}$ uređenjem odnosa za ovu vrstu mreže, te najčešće i potpuno izdvajanje od održavanja ostatka putne mreže.

Ocena postojećih kapaciteta za održavanje puteva je obuhvatila:

- detaljnu analizu postojećih uslova i uređenosti odnosa kod održavanja putne mreže;

- pregled i ocenu stanja u regionalnim jedinicama za održavanje puteva;

- utvrđivanje da li postojeće regionalne jedinice poseduju sredstva i kapacitet za izvršavanje zadataka održavanja autoputeva u budućnosti;

- pregled i ocenu tržišta uz utvrđivanje da li privatni sektor poseduje dovoljno kapaciteta za preduzimanje aktivnosti održavanja autoputeva;

- detaljnu analizu zakona, postojeće prakse i ograničenja, uz davanje preporuka, u vezi sa mogućnosću ugovaranja radova održavanja sa privatnim sektorom.

$\mathrm{Na}$ osnovu trenutne uređenosti i kapaciteta, kao i u svetlu institucionalnih promena unutar Agencije za državne puteve, utvrđeno je da izvođači iz javnog sektora mogu u određenom periodu obavljati aktivnosti održavanja autoputeva, i to najmanje dok Jedinica za autoputeve ne bude u potpunosti sposobna da preuzme sve aktivnosti upravljanja, kao i dok se preduzeća iz privatnog sektora ne prilagode novoj praksi.

Međutim, ovakav predlog mora biti praćen organizacionim promenama u pogledu redukovanja postojećih regionalnih jedinica za održavanje puteva kroz formiranje specijalizovanih regionalnih jedinica za održavanje autoputeva koje će biti odgovorne za duže sekcije/sektore od oko 200-300 km.

\section{OSNOVNI USLOVI ZA ORGANIZOVANJE RADOVA REDOVNOG ODRŽAVANJA}

Redovno održavanje se generalno može definisati kao trajan proces manjih, brzih intervencija na putevima sa glavnom svrhom da se postojeći putevi, čije karakteristike ispunjavaju zahteve za određenu vrstu saobraćaja, sačuvaju u stanju koje pruža bezbednu, udobnu i ekonomičnu upotrebu tokom čitave godine.

Primarne aktivnosti redovnog održavanja puteva obuhvataju sledeće radove:

- pregledi, utvrđivanje i ocena stanja puteva i putnih objekata;

- ograničene popravke oštećenja kolovozne konstrukcije, trupa puta i putnih objekata;

- čišćenje površine kolovoza i putnog pojasa;

- uređenje i popravke bankina, bermi i kosina;

- čišćenje, uređenje i popravke sistema za odvodnjavanje;

- čišćenje, uređenje i popravke saobraćajne signalizacije i opreme;

- kontrola vegetacije u okviru putnog pojasa;

- uklanjanje snega i leda sa saobraćajnih površina. 
Sve radove redovnog održavanja puteva bi, po pravilu, trebalo da obavlja adekvatno kvalifikovana jedinica ili preduzeće za održavanje puteva. Korišćenjem savremenih tehnoloških postupaka, gde je ručni rad u velikoj meri zamenjen mašinskim, mora se obezbediti kvalitet radova održavanja, efikasnost i ekonomičnost. Uslov za to je i adekvatan profesionalni nivo kadrova.

Jedinica za održavanje puteva, registrovana za pružanje delatnosti održavanje puteva putem ugovornog odnosa, mora biti kvalifikovana da obavlja sledeće zadatke:

- blagovremeno organizovanje i obavljanje svih neophodnih poslova i zadataka kako bi putevi konstantno omogućili bezbedno i neprekidno odvijanje saobraćaja (posebno tokom zime i za vreme elementarnih nepogoda);

- ekonomično i kvalitetno obavljanje radova korišćenjem odgovarajuće mehanizacije i ugradnja kvalitetnih materijala, u skladu sa postojećom tehničkom regulativom za predmetne radove;

- pouzdana kontrola korišćenih materijala i izvedenih radova;

- stalno unapređenje tehnologije rada, korišćenje novih materijala i neprekidno i ekonomično unapređenje organizacije sa prilagođavanjem različitim zadacima i uslovima rada.

Za obavljanje ovih poslova, jedinica za održavanje treba da obezbedi sledeće:

- tehnološki i organizaciono unapređene radne procedure (ručni rad jednog čoveka se menja mehaničkim radom i radnom grupom);

- kadrove obučene za održavanje puteva korišćenjem moderne opreme i tehnologije;

- sistematsko stručno planiranje radova održavanja u odnosu na trenutno stanje puteva i zahteve saobraćaja;

- stalna i stroga kontrola kvaliteta radova i materijala.

Organizacija radova održavanja može biti veoma različita zbog specifičnih uslova (npr. stanje puteva, saobraćajna potražnja, opremljenost i dr), ali je ipak potrebno imati u vidu sledeće:

- osnovna funkcija jedinice za održavanje puteva je održavanje puteva i ovaj zahtev mora da se ispuni;

- vrsta opreme i mehanizacije je uslovljena specifičnim radovima održavanja puteva;

- izgradnja i rekonstrukcija/rehabilitacija puteva, kao i druge građevinske aktivnosti, se mogu pojaviti samo kao dopunske delatnosti nakon ispunjavanja osnovnog zadatka.

Veći obim saobraćaja motornih vozila na autoputu predviđa i viši organizacioni nivo tokom izvođenja radova, ali i povišen novo brige za bezbednost radnika. Mehanička oprema prilagođena za radove redovnog održavanja puteva ima mali kapacitet, ali u suštini omogućava lakše, brže i kvalitetnije obavljanje radova za razliku od ručnog rada koji se u prošlosti češće praktikovao. Da bi se koristilo mašinsko održavanja puteva potrebno je prilagoditi poprečni profil puta, opremu i putni pojas, o čemu se vodi računa prilikom projektovanja.

U različitim uslovima obavljanja redovnog održavanja puteva, bilo kao reaktivno ili preventivno, radovi se moraju izvršiti:

- što je pre moguce;

- kada su uslovi odvijanja saobraćaja, vremenski i drugi uslovi najpogodniji (u periodima manjeg saobraćajnog opterećenja, bez ograničenja ako je moguće, u toku dnevnog vremena, pri odgovarajućim temperaturama i bez padavina i sl);

- upotrebom odgovarajućih mera bezbednosti na radnom mestu, što pre svega zavisi od gustine saobraćaja motornih vozila, kao i vrste i obima radova. 
Izvođenje radova redovnog održavanja puteva je zahtevan proces jer većina radnji nije uslovljena potpunim zatvaranjem puta tako da radovi predstavljaju poremećaj saobraćaja, a radnici i učesnici u saobraćaju su u stalnoj opasnosti. Radne lokacije na putevima su u većini slučajeva prepreka protoku saobraćaja pa se moraju jasno označiti i obezbediti do potpunog okončanja radova. Po završetku radova, odnosno kada više nema potrebe za obeležavanjem radnih lokacija, mere i ograničenja treba ukinuti. Tokom planiranja radova u okviru redovnog održavanja puteva neophodno je da se omogući i minimum uslova bezbednosti za učesnike u saobraćaju (npr. širina saobraćajne trake, stanje kolovozne površine, signali i saobraćajni znaci).

\section{MREŽA AUTOPUTEVA U AZERBEJDŽANU}

Važan zadatak u okviru razvojnog plana Vlade Republike Azerbejdžan je unapređenje dela državne mreže puteva do nivoa međunarodnih standarda usluge. Od 2006. godine su uložena značajna sredstva, i to uglavnom u unapređenje glavnih magistralnih puteva. Cilj Vlade je da četiri glavna pravca (M1, M2, M3 i M4) dostignu međunarodne standarde za nivo autoputeva po tehničkim i geometrijskim karakteristikama, bezbednosti saobraćaja, signalizaciji, uslugama za korisnike puteva kao što su odmorišta, organizacija eksploatacije i održavanja, uslužno-servisne delatnosti, te konačno postizanje održivih mehanizama finansiranja. Ova četiri pravca čine ukupno oko $1.230 \mathrm{~km}$, od čega je u dužini od oko $300 \mathrm{~km}$ već izgrađeno sa profilom od četiri ili više traka. U narednom petogodišnjem periodu Vlada planira da unapredi dodatnih $700 \mathrm{~km}$ tako da bi do kraja 2015. godine oko $1.000 \mathrm{~km}$ puteva trebalo da poseduje standard autoputa, a krajem 2018. godine i svih $1.230 \mathrm{~km}$.

Osim ove osnovne mreže u plan održavanja treba uključiti i dodatne važne autoputne pravce, prvenstveno u okolini ili kroz veće gradove. Osnovni podaci o putnoj mreži koja je predmet viših zahteva u vezi sa održavanjem i nivoom usluge prema korisnicima, prikazani u Tabeli 1, su dobijeni iz baze podataka Agencije za državne puteve.

\section{PROCENA KAPACITETA REGIONALNIH JEDINICA ZA ODRŽAVANJE}

Kombinovane regionalne jedinice bi u potpunosti bile opremljene za obavljanje radova redovnog i zimskog održavanja (gde je to potrebno imajući u vidu klimatske karakteristike u Azerbejdžanu), te sa određenom specijalizovanom opremom za tipične popravke kolovoza, hitne i preventivne radove održavanja. Važan aspekt ovakve organizacije je "nezavisnost" od Agencije za državne puteve u odnosu na kapacitete javnih nabavki, kako bi mogle biti ugovorene posebne vrste usluga, iznajmljivanje opreme ili podugovaranje nekih od aktivnosti. Jedinice takođe moraju da imaju laboratoriju za kontrolu kvaliteta i radionicu za servisiranje i popravku opreme, te nekoliko tehničkih stručnjaka koji bi se bavili dnevnim pregledima puteva, procenom stanja puteva, upravljanjem putevima, pitanjima bezbednosti saobraćaja, kontrolom kvaliteta, procenom troškova, upravljanjem korišćenjem opreme, bazom podataka, i dr. Takođe bi bilo dobro da se razmotri uspostavljanje specijalizovanog servisa za saobraćajnu signalizaciju u okviru svake od 
ovih regionalnih jedinica ili kao posebne jedinice za kompletnu mrežu autoputeva, radi proizvodnje i postavljanja signalizacije.

Tabela 1. Karakteristike osnovne putne mreže u Azerbejdžanu

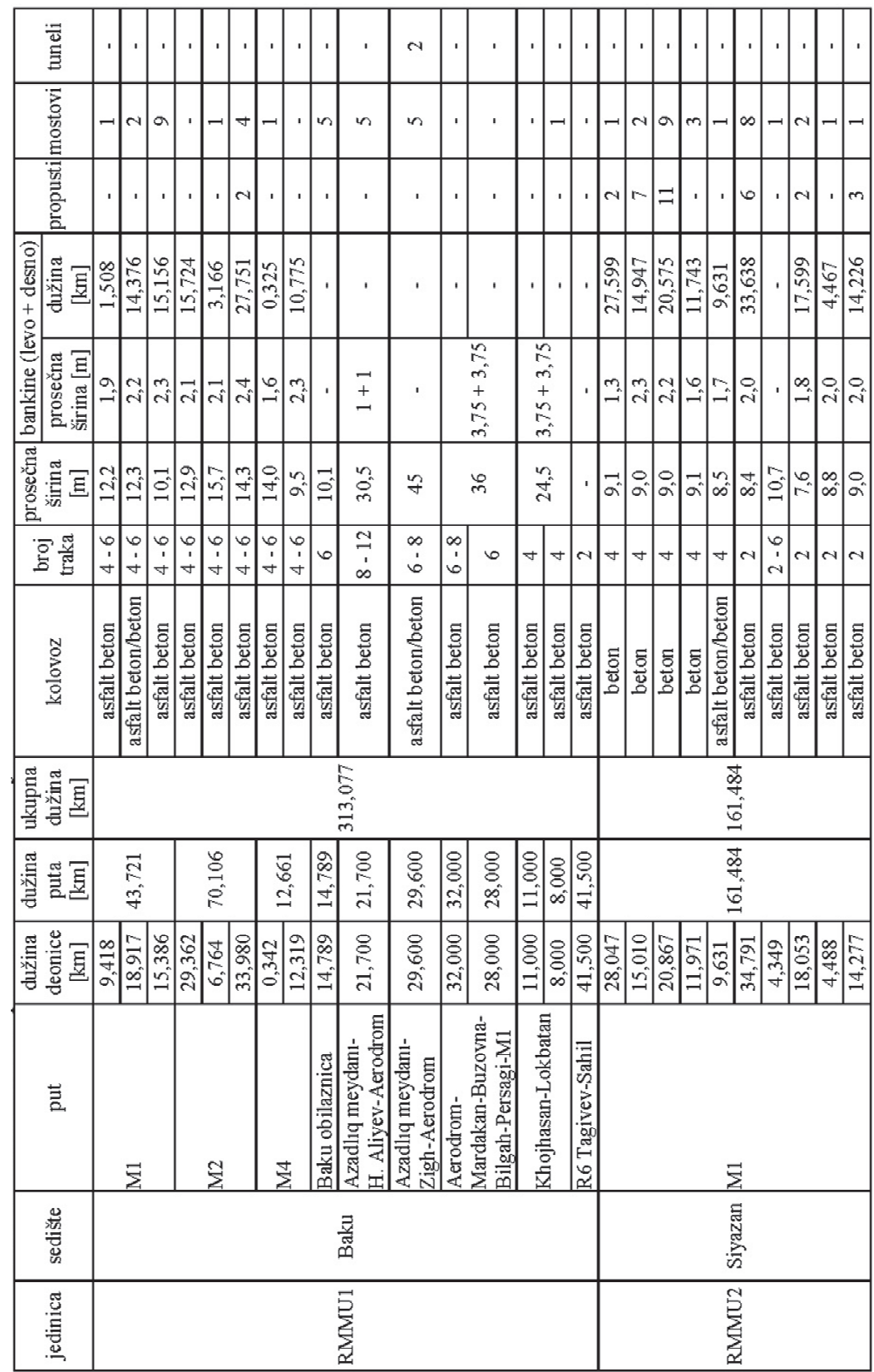


Tabela 1. Karakteristike osnovne putne mreže u Azerbejdžanu

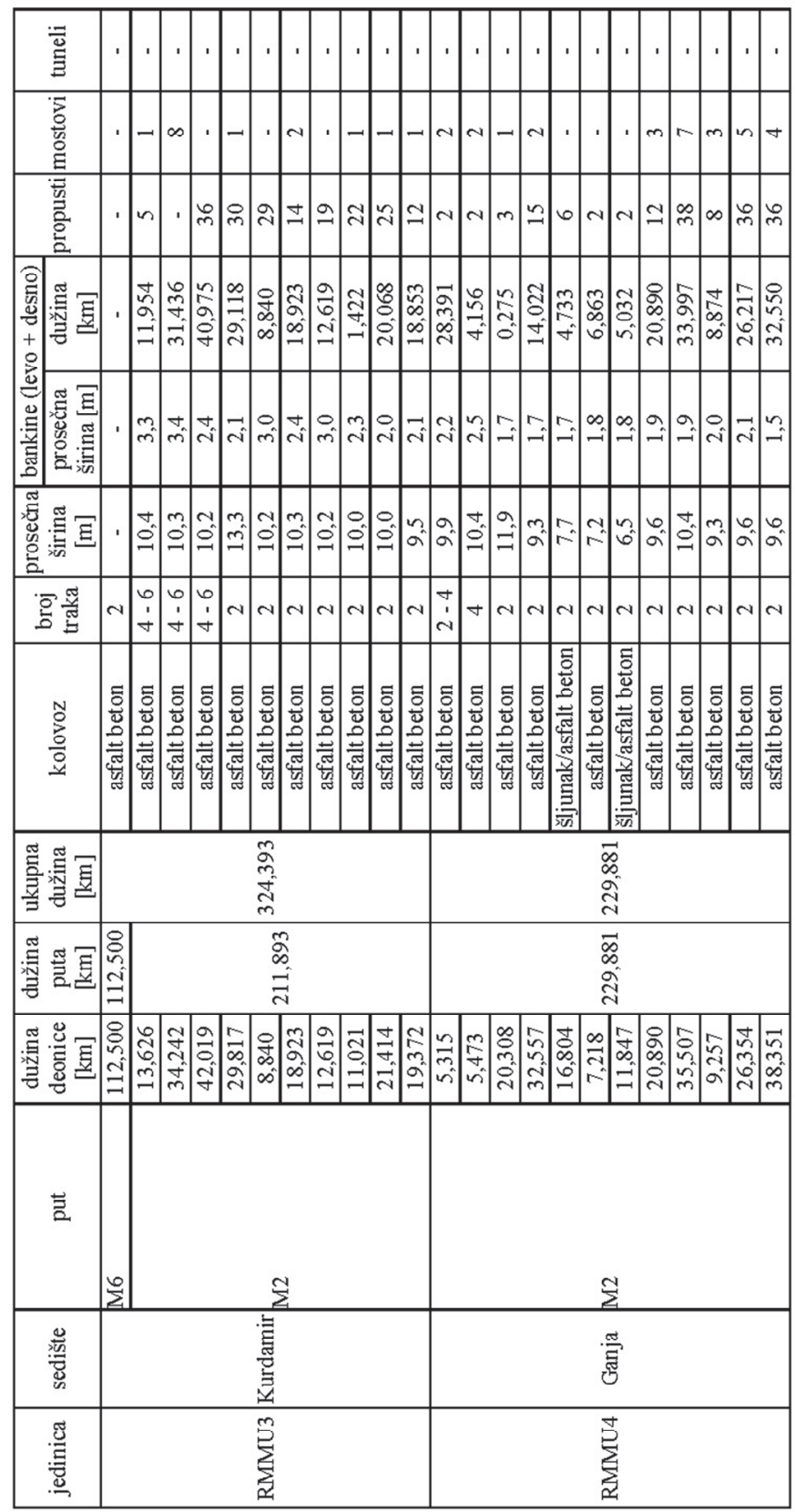


Tabela 1. Karakteristike osnovne putne mreže u Azerbejdžanu

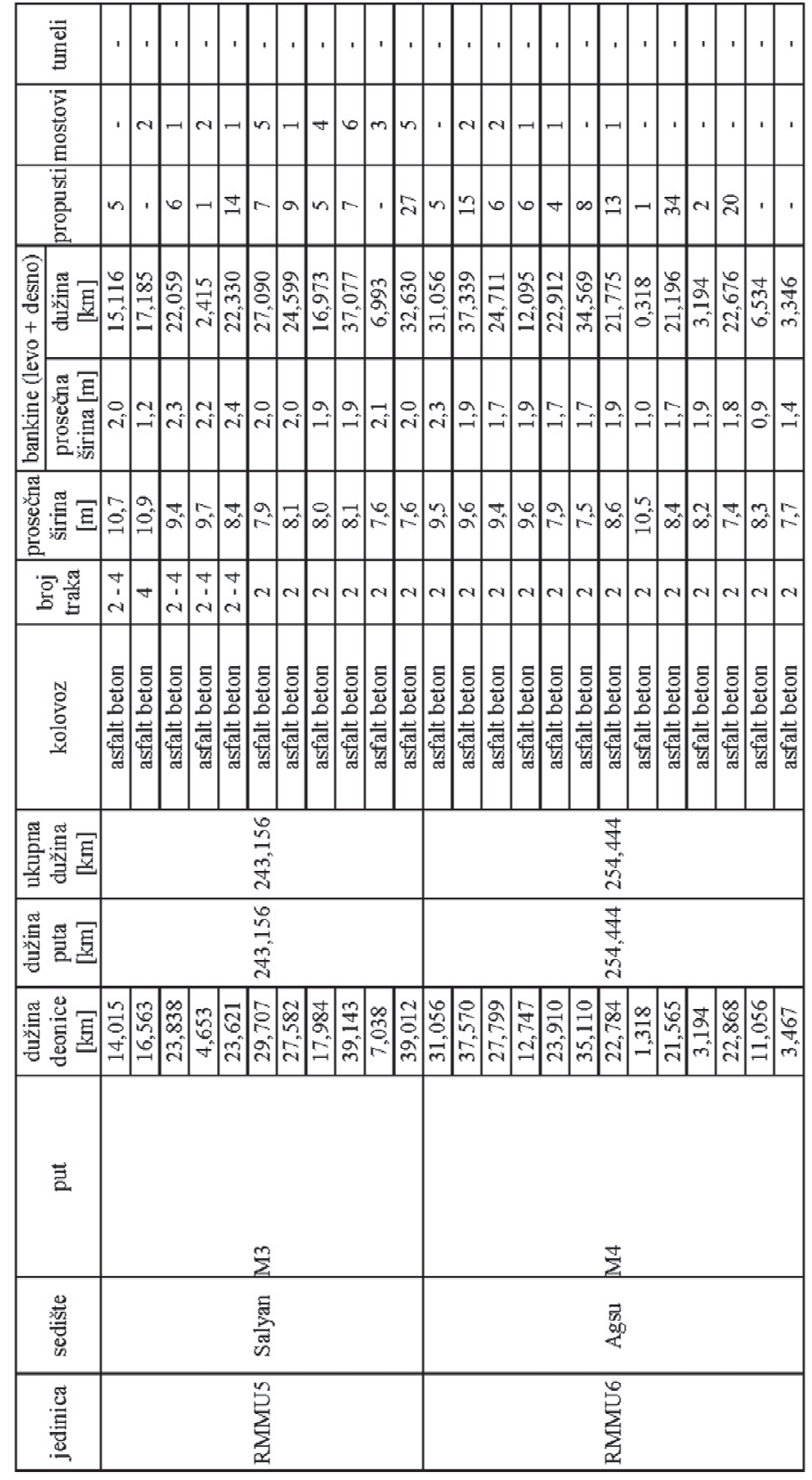


Lokacije i mreža koju pokrivaju predložene regionalne jedinice su prikazane na Slici 1.

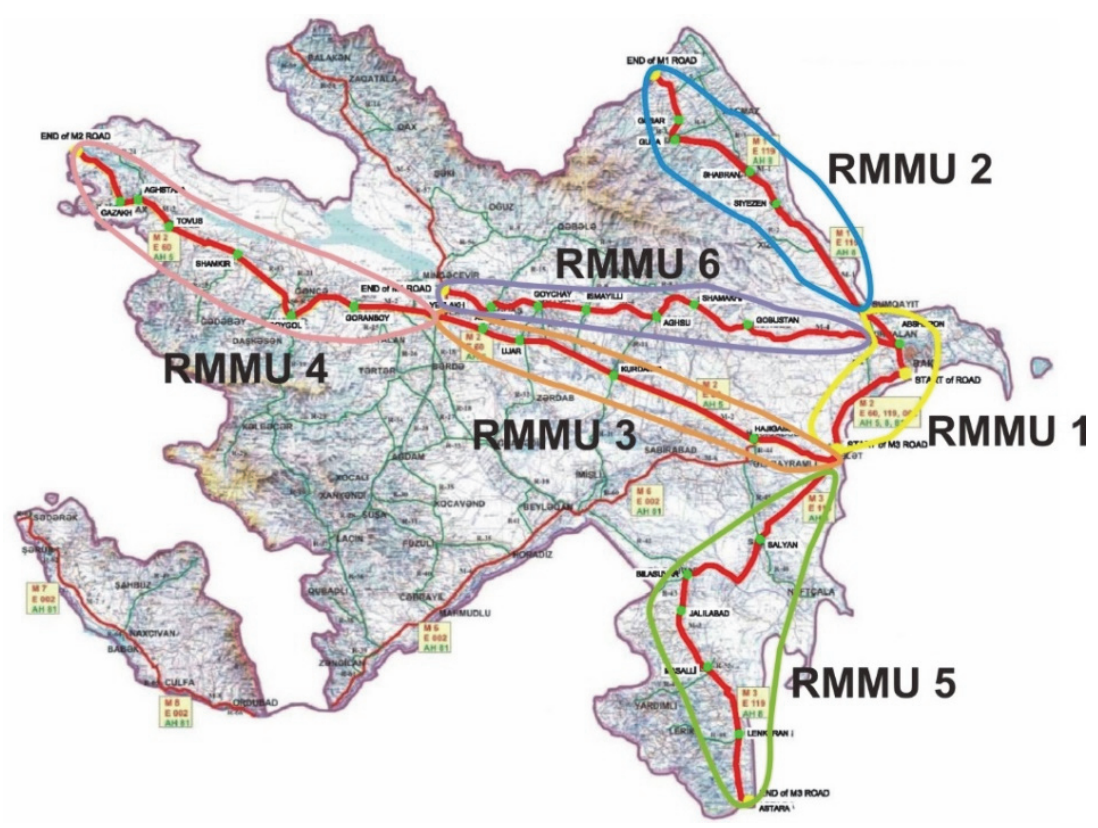

Slika 1. Predložena raspodela osnovne putne mreže po regionalnim jedinicama

Predložena raspodela, kako je prikazana na Slici 1. i u Tabeli 1, je dobijena nakon provođenja komparativne analize uz korišćenje SWOT (Strenghts-WeaknessesOpportunities-Threats) metode, pri čemu je pristup problemu moguć sa dve različite pozicije:

- "statičko" razmatranje u odnosu na prednosti i nedostatke (Strengths + Weaknesses) postojećeg sistema koje omogućavaju ili ograničavaju aktivnosti;

- "dinamičko" razmatranje u odnosu na mogućnosti i rizike (Opportunities + Threats) koje bi eventualno mogle da utiču na buduće aktivnosti.

Analizirano je šest opcija organizacije polazeći od postojećeg sistema bez uvođenja promena, preko linearnog pristupa različitog obima zadataka i obaveza između Agencije za državne puteve i izvođača, do sveukupnog održavanja mreže putem nekog vida koncesije ili sl. Predložena opcija, bez većeg oslanjanja na privatni sektor u početnom periodu realizacije, će omogućiti da se javni sektor razvija u oblasti upravljanja putnim kapitalom/imovinom i održavanju puteva prema definisanom nivou usluge, te istovremeno omogućiti specijalizaciju i profesionalizaciju jedinica za održavanje puteva.

Potrebe u kadrovima i opremi su procenjene na osnovu dužine puteva i širine kolovoza (površina kolovoza), i standarda održavanja puteva za slične uslove u jugoistočnoj Evropi. U Tabeli 2. su prikazani rezultati dobijeni za procenu kapaciteta opreme za normalno funkcionisanje redovnog održavanja puteva, dok se u Tabeli 3. daju rezultati za procenu kadrovskih potreba. Zbirne vrednosti su prikazane u Tabeli 4. Na Slici 2. je prikazan opšti izgled jedne regionalne jedinice sa rasporedom pojedinih sadržaja u okviru depoa, dok su troškovi izgradnje na osnovu ovakve šeme dati u Tabeli 4. 
Tabela 2. Procena potrebne količine opreme i troškova za nabavku

\begin{tabular}{|c|c|c|c|c|c|c|c|c|}
\hline r.br. & vrsta opreme & \begin{tabular}{|c|} 
jedinična \\
cena $[€]$
\end{tabular} & Baku & Siyazan & Kurdamir & Ganja & Salyan & Agsu \\
\hline 1. & finišer (srednji) & 300.000 & 2 & 1 & 1 & 1 & 1 & 1 \\
\hline 2. & glodalica (radna širina $2 \mathrm{~m}$ ) & 300.000 & 1 & 1 & 1 & 1 & 1 & 1 \\
\hline 3. & mašina za sečenje asfalta & 5.000 & 2 & 2 & 2 & 2 & 2 & 2 \\
\hline 4. & mali kamion (nosivost $\leq 2 \mathrm{t}$ ) & 30.000 & 8 & 4 & 8 & 6 & 8 & 8 \\
\hline 5. & kamion cisterna (kapacitet $8 \mathrm{t}$ ) & 80.000 & 2 & 1 & 1 & 1 & 1 & 1 \\
\hline 6. & teški kamion (nosivost $>10 \mathrm{t})$ & 120.000 & 30 & 15 & 20 & 12 & 15 & 15 \\
\hline 7. & kamion sa prikolicom & 150.000 & 2 & 1 & 2 & 2 & 2 & 2 \\
\hline 8. & utovarivač & 90.000 & 3 & 1 & 3 & 3 & 3 & 3 \\
\hline 9. & $\begin{array}{l}\text { kombinovana mašina } \\
\text { (utovarivač-bager) }\end{array}$ & 90.000 & 4 & 2 & 2 & 2 & 2 & 2 \\
\hline 10. & bager & 120.000 & 3 & 2 & 3 & 3 & 3 & 3 \\
\hline 11. & grejder & 120.000 & 2 & 1 & 2 & 2 & 2 & 2 \\
\hline 12. & $\begin{array}{l}\text { valjak sa čeličnim točkovima } \\
\text { (težina } \leq 2 \mathrm{t} \text { ) }\end{array}$ & 40.000 & 2 & 1 & 1 & 1 & 1 & 1 \\
\hline 13. & $\begin{array}{l}\text { valjak sa čeličnim točkovima } \\
\text { (težina } \leq 6 \mathrm{t} \text { ) }\end{array}$ & 60.000 & 4 & 2 & 2 & 2 & 2 & 2 \\
\hline 14. & valjak sa gumenim točkovima & 90.000 & 2 & 1 & 1 & 1 & 1 & 1 \\
\hline 15. & mali tandem valjak & 25.000 & 4 & 2 & 2 & 2 & 2 & 2 \\
\hline 16. & vibracioni nabijač & 5.000 & 2 & 2 & 2 & 2 & 2 & 2 \\
\hline 17. & kompresor za vazduh & 7.000 & 2 & 1 & 1 & 1 & 1 & 1 \\
\hline 18. & pneumatska bušilica & 4.000 & 2 & 1 & 1 & 1 & 1 & 1 \\
\hline 19. & sekačica za asfalt/beton & 1.000 & 6 & 4 & 6 & 6 & 6 & 6 \\
\hline 20. & $\begin{array}{l}\text { mašina za zalivanje pukotina } \\
\text { (kapacitet } \geq 5001 \text { ) }\end{array}$ & 45.000 & 1 & & & & & \\
\hline 21. & $\begin{array}{l}\text { mašina za zalivanje pukotina } \\
\text { (kapacitet } \geq 501 \text { ) }\end{array}$ & 3.000 & 3 & 2 & 2 & 2 & 2 & 2 \\
\hline 22. & kosačica & 2.000 & 2 & 2 & 2 & 2 & 2 & 2 \\
\hline 23. & $\begin{array}{l}\text { oprema za sečenje trave i } \\
\text { žbunja }\end{array}$ & 10.000 & 2 & 2 & 2 & 2 & 2 & 2 \\
\hline 24. & dodatna oprema za pranje & 10.000 & 2 & 2 & 2 & 2 & 2 & 2 \\
\hline 25. & $\begin{array}{l}\text { oprema za popravku zaštitne } \\
\text { ograde }\end{array}$ & 40.000 & 1 & 1 & 1 & 1 & 1 & 1 \\
\hline 26. & putničko vozilo & 20.000 & 5 & 4 & 4 & 5 & 5 & 5 \\
\hline 27. & $\begin{array}{l}\text { mašina za horizontalnu } \\
\text { signalizaciju }\end{array}$ & 50.000 & 1 & 1 & 1 & 1 & 1 & 1 \\
\hline 28. & $\begin{array}{l}\text { komplet saobraćajne } \\
\text { signalizacije za obeležavanje } \\
\text { radova }\end{array}$ & 4.000 & 5 & 4 & 5 & 5 & 5 & 5 \\
\hline 29. & $\begin{array}{l}\text { komplet svetlosne } \\
\text { signalizacije za obeležavanje } \\
\text { radova }\end{array}$ & 5.000 & 2 & 2 & 2 & 2 & 2 & 2 \\
\hline 30. & $\begin{array}{l}\text { univerzalna mašina (tipa } \\
\text { Unimog) }\end{array}$ & 80.000 & 6 & 2 & 3 & 4 & 4 & 4 \\
\hline 31. & jednostrani plug za sneg & 8.000 & 10 & 4 & 6 & 6 & 5 & 5 \\
\hline 32. & $\begin{array}{l}\text { jednostrani plug za sneg za } \\
\text { univerzalnu mašinu }\end{array}$ & 7.000 & 6 & 2 & 3 & 4 & 4 & 4 \\
\hline 33. & automatski posipač & 15.000 & 10 & 4 & 6 & 6 & 5 & 5 \\
\hline 34. & $\begin{array}{l}\text { posipač za univerzalnu } \\
\text { mašinu }\end{array}$ & 13.000 & 6 & 2 & 4 & 4 & 4 & 4 \\
\hline \multirow[t]{2}{*}{35.} & rotaciona grtalica za sneg & 15.000 & 2 & 2 & 2 & 2 & 2 & 2 \\
\hline & & ukupno [€] & 8.256 .000 & 4.283 .000 & 5.738 .000 & 4.825 .000 & 5.222 .000 & 5.222 .000 \\
\hline
\end{tabular}


Tabela 3. Procena potrebnih kadrovskih kapaciteta

\begin{tabular}{|l|l|c|c|c|c|c|c|}
\hline r.br. & \multicolumn{1}{|c|}{ kadar } & Baku & Siyazan & Kurdamir & Ganja & Salyan & Agsu \\
\hline 1. & rukovodilac jedinice & 1 & 1 & 1 & 1 & 1 & 1 \\
\hline 2. & $\begin{array}{l}\text { rukovodilac redovnog i zimskog } \\
\text { održavanja }\end{array}$ & 1 & 1 & 1 & 1 & 1 & 1 \\
\hline 3. & službenik za zaštitu puteva & 1 & 1 & 1 & 1 & 1 & 1 \\
\hline 4. & mašinski inženjer & 1 & 1 & 1 & 1 & 1 & 1 \\
\hline 5. & saobraćajni inženjer & 1 & 1 & 1 & 1 & 1 & 1 \\
\hline 6. & inženjer za planiranje i projektovanje & 1 & 1 & 1 & 1 & 1 & 1 \\
\hline 7. & inženjer za osiguranje i kontrolu kvaliteta & 1 & 1 & 1 & 1 & 1 & 1 \\
\hline 8. & terenski inženjeri & 3 & 3 & 2 & 2 & 2 & 2 \\
\hline 9. & $\begin{array}{l}\text { inženjer za zaštitu životne sredine, } \\
\text { bezbednost i zdravlje na radu }\end{array}$ & 1 & 1 & 1 & 1 & 1 & 1 \\
\hline 10. & službenik za odnose da javnošću & 1 & 1 & 1 & 1 & 1 & 1 \\
\hline 11. & službenik za tehničku dokumentaciju & 2 & 2 & 2 & 2 & 2 & 2 \\
\hline 12. & predradnik & 5 & 4 & 3 & 3 & 3 & 3 \\
\hline 13. & putar & 45 & 25 & 45 & 30 & 30 & 30 \\
\hline 14. & vozač kamiona & 40 & 21 & 31 & 21 & 26 & 26 \\
\hline 15. & mašinista & 11 & 10 & 10 & 10 & 10 & 10 \\
\hline 16. & administracija i podrška (radionice) & 20 & 10 & 20 & 20 & 20 & 20 \\
\hline & $\quad$ ukupno & 135 & 84 & 122 & 97 & 102 & 102 \\
\hline
\end{tabular}

Slika 2. Opšti izgled sadržaja u okviru regionalne jedinice za održavanje autoputa (A-administrativna zgrada; Ar-radionice; B-letnja garaža; B1-zimska garaža; $C$ skladište zaštitnih ograda; D-deponija posipnog materijala; E-stanica za gorivo; $F$ dnevni servis i pranje vozila; G1-skladište; H-dopunski objekti)

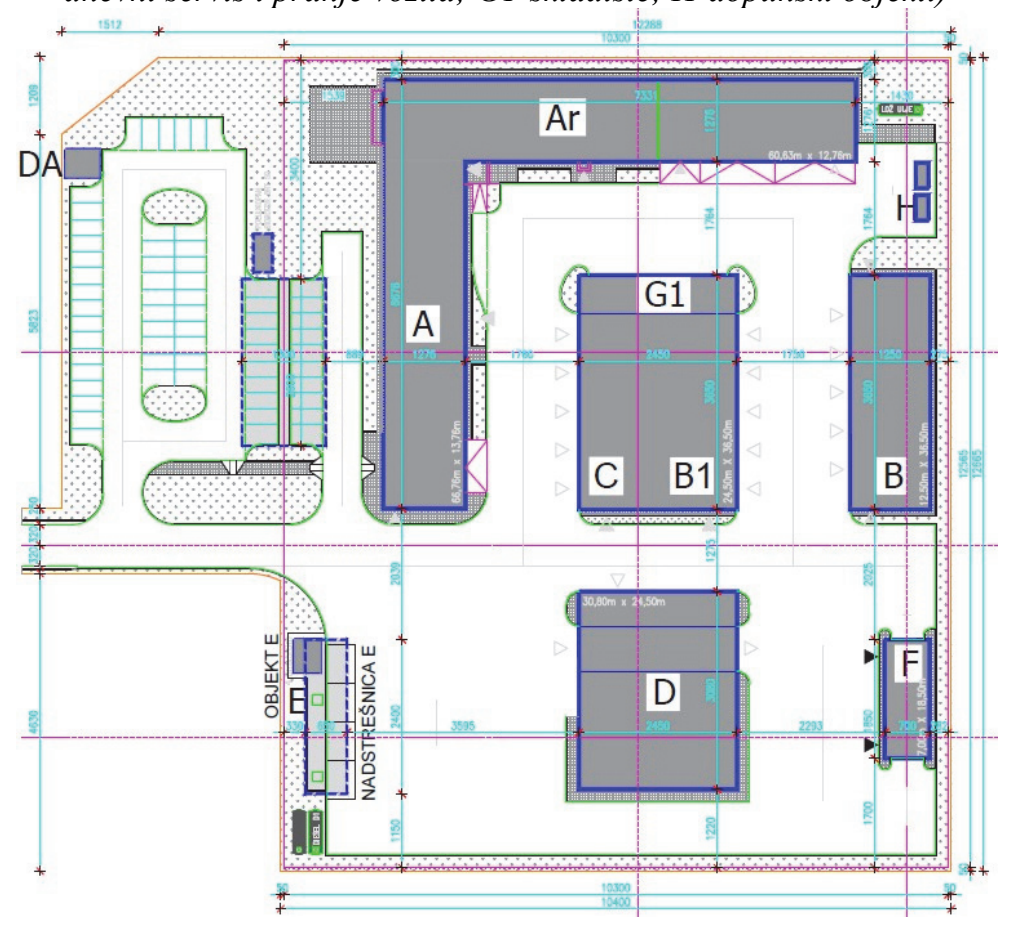


Tabela 4. Zbirni troškovi osnivanja jedinica za održavanje autoputeva u Azerbejdžanu

\begin{tabular}{|c|c|c|c|c|c|c|c|c|}
\hline \multicolumn{2}{|l|}{ jedinica } & RMMU1 & RMMU2 & RMMU3 & RMMU4 & RMMU5 & RMMU6 & \multirow{2}{*}{ ukupno } \\
\hline \multicolumn{2}{|l|}{ sedište } & Baku & Siyazan & Kurdamir & Ganja & Salyan & Agsu & \\
\hline \multicolumn{2}{|l|}{\begin{tabular}{|l} 
dužina $[\mathrm{km}]$ \\
\end{tabular}} & 313,077 & 161,484 & 324,393 & 229,881 & 243,156 & 254,444 & $1.526,435$ \\
\hline \multirow{3}{*}{\begin{tabular}{|l|} 
dužina za \\
održavanje \\
{$[\mathrm{km}]$}
\end{tabular}} & 2014 & 285,077 & 85,526 & 128,544 & 99,522 & 42,269 & 0 & 640,938 \\
\hline & 2016 & 313,077 & 161,484 & 211,893 & 99,522 & 243,156 & 189,988 & $1.219,120$ \\
\hline & 2018 & 313,077 & 161,484 & 211,893 & 229,881 & 243,156 & 254,444 & $1.413,935$ \\
\hline \multicolumn{2}{|c|}{ godina osnivanja } & 2015 & 2016 & 2016 & 2016 & 2017 & 2017 & - \\
\hline \multicolumn{2}{|c|}{ kapacitet [\%] } & 100 & 100 & 50 & 50 & 100 & 100 & - \\
\hline \multirow{3}{*}{$\begin{array}{l}\text { površina } \\
\text { kolovoza } \\
{\left[\mathrm{m}^{2}\right]}\end{array}$} & asfalt beton & 5.136 .615 & 643.968 & 3.254 .113 & 2.189 .314 & 2.066 .472 & 2.195 .012 & 15.485 .494 \\
\hline & beton & 811.864 & 767.878 & 0 & 0 & 0 & 0 & 1.579 .742 \\
\hline & ukupno & 5.948 .479 & 1.411 .846 & 3.254 .113 & 2.189 .314 & 2.066 .472 & 2.195 .012 & 17.065 .236 \\
\hline \multicolumn{2}{|c|}{ troškovi opreme [€] } & 8.256 .000 & 4.293 .000 & 5.738 .000 & 4.825 .000 & 5.222 .000 & 5.222 .000 & 33.556 .000 \\
\hline \multirow{3}{*}{$\begin{array}{l}\text { izgradnja } \\
\text { jedinice }\end{array}$} & $\begin{array}{l}\text { otvoren } \\
\text { prostor }\end{array}$ & 2.086 & 1.460 & 2.086 & 2.086 & 2.086 & 2.086 & 11.890 \\
\hline & \begin{tabular}{|l} 
zatvoren \\
prostor
\end{tabular} & 1.440 & 1.000 & 1.440 & 1.440 & 1.440 & 1.440 & 8.200 \\
\hline & troškovi $[€]$ & 1.305 .550 & 914.000 & 1.305 .550 & 1.305 .550 & 1.305 .550 & 1.305 .550 & 7.441 .750 \\
\hline \multicolumn{2}{|c|}{\begin{tabular}{|l} 
potreban broj \\
zaposlenih
\end{tabular}} & 135 & 84 & 122 & 97 & 102 & 102 & 642 \\
\hline
\end{tabular}

\section{ZAKLJUČAK}

Ukupni troškovi za uspostavljanje šest novih regionalnih jedinica za održavanje autoputeva su procenjeni na osnovu troškova za izvođenje radova na izgradnji jedinice i troškova nabavke opreme za održavanje puteva. Prikazane vrednosti se zasnivaju na međunarodnom iskustvu i izvedeni su iz različitih izvora (studije, podaci Evropske unije, analize međunarodnih finansijskih institucija, finansijski izveštaji, itd).

Procenjeni troškovi odražavaju realne uslove u Azerbejdžanu, te se nakon osnivanja jedinica i primene odgovarajućih programiranih mera održavanja pod rukovodstvom Jedinice za održavanje autoputeva može očekivati da će putna mreža biti u dobrom stanju održavanosti.

Međutim, bez obzira na osnivanje i opremanje jedinica za održavanje autoputeva, kako opremom, tako i kadrovski, neophodno je aktivirati kontinualan proces učenja jer se svaka strategija mora prilagođavati vremenskom trenutku u kome se realizuje. Istovremeno će jedinice za održavanje, kao i Jedinica za autoputeve u okviru Agencije za državne puteve, morati da budu u stanju da primene savremena rešenja u upravljačkom i izvođačkom domenu aktivnosti. Kako bi promene koje su predviđene mogle da budu realizovane, u veoma kratkom vremenu se mora obaviti obrazovanje osoblja i specijalistička obuka u planiranju i upravljanju aktivnosti na održavanju autoputeva.

\section{LITERATURA}

[1] Technical assistance for establishment of a motorway management unit and modernization of motorway management practices in Azerbaijan, projektna dokumentacija, 2012-2014. 


\title{
EXAMPLE FOR ESTIMATE OF THE REQUIRED CAPACITY AND COSTS TO ESTABLISH A MOTORWAY MAINTENANCE UNITS
}

\begin{abstract}
Summary: Despite the rapid expansion of the network of motorways in Azerbaijan, the organization of operation and maintenance of motorways is still not fully modernized. Currently, more than sixty regional units across the country are responsible for the maintenance of the entire road network. These units carry out their duties equally on main, regional and local roads. The modern way of operation of motorways requires a different approach with the specific procedures and regulation of relations for this type of network. Based on existing organization and capacity, as well as institutional changes/strengthening of the Agency for State Roads, it was found that operators from the public sector can provide maintenance of motorways in a certain period. Such a proposal must be accompanied by organizational changes in terms of reduction of existing units through the establishment of specialized regional units for maintenance of motorways that will be responsible for longer sections/sectors of about 200-300 km. This paper presents an analysis of the necessary capacity to maintain the motorway network in Azerbaijan, and estimate of the total costs for setting up new units for maintenance of motorways.
\end{abstract}

Keywords: operation, maintenance, capacity, costs, organization 